\title{
Local Anesthetic Activity from Extracts, Fractions and Pure Compounds from the Roots of Ottonia anisum Spreng. (Piperaceae)
}

\author{
KELVIN S.E. LÓPEZ ${ }^{1}$, ANDRÉ M. MARQUES ${ }^{2}$, DAVYSON DE L. MOREIRA ${ }^{3}$, LEOSVALDO S. VELOZO ${ }^{2}$, \\ ROBERTO T. SUDO ${ }^{1}$, GISELE ZAPATA-SUDO ${ }^{1}$, ELSIE F. GUIMARÃES ${ }^{4}$ \\ and MARIA AUXILIADORA C. KAPLAN ${ }^{2}$
}

\author{
${ }^{1}$ Programa de Pesquisa em Desenvolvimento de Fármacos, Instituto de Ciências Biomédicas, Universidade Federal \\ do Rio de Janeiro/UFRJ, Av. Brigadeiro Trompowski, s/n, Ilha do Fundão, 21941-902 Rio de Janeiro, RJ, Brazil \\ ${ }^{2}$ Instituto de Pesquisas de Produtos Naturais/IPPN, Universidade Federal do Rio de Janeiro/ \\ UFRJ, Av. Carlos Chagas Filho, 373, 21941-902 Rio de Janeiro, RJ, Brazil \\ ${ }^{3}$ Laboratório de Produtos Naturais, PN5, Far-Manguinhos, FIOCRUZ, Rua Sizenando \\ Nabuco, 100, Manguinhos, 21041-250 Rio de Janeiro, RJ, Brazil \\ ${ }^{4}$ Instituto de Pesquisas Jardim Botânico do Rio de Janeiro, Rua Pacheco Leão, \\ 915, Jardim Botânico, 2240-030 Rio de Janeiro, RJ, Brazil
}

Manuscript received on November 11, 2015; accepted for publication on March 18, 2016

\begin{abstract}
Piperaceae species can be found worldwide in tropical and subtropical areas and many of them have been used for centuries in traditional folk medicine and in culinary. In Brazil, species of Piperaceae are commonly used in some communities as local anesthetic and analgesic. Countrified communities have known some species of the genus Ottonia as "anestesia" and it is a common habit of chewing leaves and roots of Ottonia species to relief toothache. The purpose of this study is to report our findings on new molecules entities obtained from the roots of Ottonia anisum Spreng, in which local anesthetic activity (sensory blockage) is demonstrated for the first time in vivo guinea pig model. Phytochemical investigation led to the isolation of three amides (pipercallosidine, piperine and valeramide) and in an enriched mixture of seven amides (valeramide, 4,5-dihydropiperlonguminine, $\mathrm{N}$-isobutil-6-piperonil-2-hexenamide, piperovatine, dihydropipercallosidine, pipercallosidine and pipercallpsine). Our findings demonstrated the anesthetic potential for the methanolic extract from roots, its $n$-hexane partition and amides from $O$. anisum and it is in agreement with ethnobotanical survey.
\end{abstract}

Key words: Piperaceae, Piper, Ottonia, amides, anesthetic properties, sensory blockage.

\section{INTRODUCTION}

Brazil, a megadiverse country, has about 500 Piperaceae species distributed in the genera Piper, Peperomia, Zipelia and Manekia (Jaramillo and Manos 2001). Many species of the genus Piper, the

Correspondence to: André Mesquita Marques

E-mail: andrefarmaciarj@yahoo.com.br most representative of the Piperaceae, have been used for centuries in traditional folk medicine and in culinary (Parmar et al. 1997, Oliveira et al. 2013, Bezerra et al. 2013, Picard et al. 2014). Piperine was the first amide isolated from P. nigrum (black pepper) and is responsible for the characteristic pungency of this plant (Ahmad et al. 2012, Qiu et al. 
2014). Many bioactive amides from Piper species were already chemically and pharmacologically investigated (Parmar et al. 1998, Ahmad et al. 2012, Bezerra et al. 2013).

Ethnobotanical studies in South and Central Americas have showed the local anesthetic potential of many Piperaceae species. In Brazil Piper species is commonly used in some communities as local anesthetic and analgesic (McFerren and Rodriguez, 1998, McFerren et al. 2002, Agra et al. 2007). The rural communities have known some species of the genus Ottonia as "anestesia" and it is common to chewy leaves and roots of Ottonia species to relief toothache (Gottlieb 1982, Makapljgay et al. 1983, Colvard et al. 2006). Ottonia anisum Sprengel is a shrub commonly found in Southeast of Brazil. This species is known as "jaborandi" or "joãoborandi" and it is commercialized in open-air markets in the State of Rio de Janeiro. O. anisum is used in the traditional medicine and in religious rituals (Parente and Rosa 2001, Azevedo and Silva, 2006, Leitão et al. 2014). Previous phytochemical investigation of $O$. anisum resulted in the isolation and identification of amides piperovatine and $(2 E$, $4 E$ )- $N$-isobutyl-9-piperonyl-nona-2,4-dienoic from the leaves, 1-butyl-3,4-methylenedioxybenzene from the leaves and roots as well as aristolactams from the roots (Marques et al. 2008, 2011, Moreira et al. 1997, Giesbrecht et al. 1981).

Local anesthetics (LAs) reversibly block the generation and propagation of action potentials, preventing the transient increase in the permeability of excitable membranes to sodium (Lipkind and Fozzard 2005, Culp and Culp 2001). Exposure of nerve fibers to LAs causes reversible pain sensation relief without affecting the consciousness. Topical and regional anesthesia, prevention or treatment of pain and control of the ventricular arrhythmias are the main uses of LA's (Nau and Wang 2004). Cocaine, the active compound isolated from the leaves of Erythroxylum coca Lam., was introduced for clinical use by Carl Koller in 1884. Despite the identification of systemic toxic effects, including drug dependency, cocaine was clinically used until 1914 (De Araújo et al. 2003), when it was replaced by the first synthetic LA, procaine, synthesized by Einhornin in 1905 . With higher potency and duration of effect than procaine, tetracaine, also an esther local anesthetic, was introduced for clinical use in 1935 (Ernst et al. 1995). However, animal and human study showed the potential systemic toxicity induced by tetracaine (Kim et al. 2001). The new generation of local anesthetic started with lidocaine synthesized in 1943 by Löfgren and Lundquist, in which the main novelty was the replacement of esther moiety to amide (Dippenaar 2007). Systemic safety was another feature of lidocaine, however, with the disadvantage of causing a short duration of action. After 20 years, bupivacaine was clinically introduced and it became the most commonly used LA due to high potency and prolonged duration of effect. However, clinical reports showed severe systemic reaction including cardiac arrhythmias and death with the use of bupivacaine (Karya et al. 2012). A safer local anesthetic, ropivacaine, with less cardiac toxicity effect and same potency in comparison with bupivacaine was introduced in 1985 (Ruetsch et al. 2001). In spite of large efforts to find new molecules with local anesthetic activity with low toxicity, any new substance was introduced for clinical use in the past 30 years. The purpose of this study is to report our findings on new molecules entities obtained from the plant Ottonia anisum Spreng., in which local anesthetic activity is demonstrated for the first time in vivo animal model.

The crude methanolic extract (OAR-MeOH) as well as the non-polar $n$-hexane partition (OAR-PH) were previously tested for anesthetic activity. The non-polar partition OAR-PH was chromatographed over silica gel column guided by the promising anesthetic potential. Phytochemical investigation resulted in enriched mixture of seven amides (MIXAMD, valeramide, 
<smiles>O=C(/C=C/C=C/c1ccc2c(c1)OCO2)N1CCCCC1</smiles><smiles>CC(C)CNC(=O)/C=C/CCCCc1ccc2c(c1)OCO2</smiles>

pipercallosidine<smiles>CC(C)CNC(=O)CCCCc1ccc2c(c1)OCO2</smiles><smiles>CC(C)CNC(=O)CCCCCCc1ccc2c(c1)OCO2</smiles>
dihydropipercallosidine<smiles>COc1ccc(C/C=C/C=C/C(=O)NCC(C)C)cc1</smiles>
piperovatine<smiles>CC(C)CNC(=O)/C=C/CCc1ccc2c(c1)OCO2</smiles>

4,5-dihydropiperlonguminine

Figure 1 - Characterized amides from roots of $O$. anisum Sprengel.

4,5-dihydropiperlonguminine, $\mathrm{N}$-isobutil6-piperonil-2-hexenamide, piperovatine, dihydropipercallosidine, pipercallosidine and pipercallpsine) as well as in pure compounds pipercallosidine (AMD1), piperine and valeramide, Figure 1. Only pipercallosidine of all three isolated amides could be assayed due to the affordable amount. The characterized metabolites found in $O$. anisum root extract were in agreement with those from literature data for Piperaceae species (Parmar et al. 1997, Ahmad et al. 2012, Greger 2016) but just piperovatine and the amide (2E, 4E)- $N$-isobutyl-9-piperonyl-nona-2,4-dienoic have been described for $O$. anisum (Giesbrecht et al. 1981). Species of the genus Piper and Ottonia have been related as natural sources for alkylamides. From roots of $O$. corcovadensis Costa and Mors (1981) isolated 5 amides (piperovatine, piperlonguminine, isopiperlonguminine, corcovadine and isocorcovadine). From aerial parts of $O$. martiana it was isolated the amides piperovatine and piperlonguminine (Cunico et al. 2005). In addition, literature data reported that the amide piperovatine has been isolated from Piper piscatorum, Piper callosum, P. hancei, $P$. alatabaccum, Ottonia anisum, O. corcovadensis, $O$. ovata, and O. vahlii (Colvard and Cordell 2008). Many $N$-alkylamides have been isolated from Piperaceae species. The structural similarity of these amides is a challenge to the isolation of them from the mixtures. By this mean, GC-MS is a power tool to identify known amides from mixtures. $\mathrm{N}$-alkylamides from Piperaceae, generally, have a straight chain moiety with or without aromatic group in the end of the chain. In the case of aromatic ring, it is often a 3,4-methylenedioxy substituted and the acid chain has an uneven number of carbon atoms $(n=1,3,5,7,9,11,13$ and 15). But it is 
also possible an even number of carbon atoms such as piperovatine $(n=6)$ and retrofractamide $\mathrm{D}(n$ $=10$ ) from $P$. retrofractum. Those $N$-alkylamides without an aromatic group in the end of the chain have an uneven number of carbon atoms such as filfiline $(n=22)$ from $P$. officinarum. The most common $N$-moiety groups are isobutyl, $n$-pentyl, isopentyl, piperidine, pyrrole and pyrrolidine (Parmar et al. 1997, Boonen et al. 2012, Greger 2016). Considering the amides isolated from $O$. anisum, here presented, six of them have an acid chain with uneven number of carbon atoms ( $n$ $=5,7$ and 9), being five with isobutyl $N$-moiety (exception for piperine). Only piperovatine and $N$-isobutil-6-piperonil-2-hexenamide have even carbon atoms in the acid chain $(n=6)$. In relation to the aromatic ring substitution pattern, seven have a 3,4-methylenedioxy substitution. Again, exception for piperovatine that has a methoxy as substituent. This chemical pattern is in agreement with those from literature records for $N$-akylamides from Piper species (Parmar et al. 1997, Boonen et al. 2012, Greger 2016). Besides, some other amides isolated from the genus Ottonia, such as piperlonguminine, corcovadine and isocorcovadine fit in this profile (Costa and Mors 1981).

The same concentration of lidocaine, crude methanolic extract (OAR-MeOH) and $n$-hexane partition (OAR-PH) as well as the pure pipercallosidine (AMD1) and amide-rich-fraction (MIXAMD) were administered by intradermal route. The figure 2 shows that the duration of sensory blockage increased in a dose-dependent manner for all tested samples and, at higher concentration (940 $\mu \mathrm{g} / \mathrm{ml})$, the blockage induced by lidocaine, OAR$\mathrm{MeOH}, \mathrm{OAR}-\mathrm{PH}, \mathrm{AMD} 1$ and MIXAMD was 55.6 $\pm 1.4,41.5 \pm 0.7,41.5 \pm 2.3,23.0 \pm 1.1$ and 25.3 \pm 0.6 minutes, respectively. This result reveals the presence of compounds with local anesthetic activity in all $O$. anisum samples. The duration of sensory block induced by $O$. anisum samples was significantly lower $(p<0.05)$ than lidocaine, except, for OAR-PH at the lowest concentration $(60 \mu \mathrm{g} / \mathrm{ml})$, in which the time of blockage was as $15.2 \pm 1.2$ and $14.5 \pm 1.9$ minutes, respectively. This finding is very relevant since OAR-PH is a rich amide fraction (see experimental). Considering OAR-MeOH, that comprises a mixture of $O$. anisum roots constituents (non-polar, medium polar and high polar compounds), the maximum activity is shown at $470 \mu \mathrm{g} / \mathrm{ml}(38.7 \pm 1.9 \mathrm{~min})$ and there is dose-dependent decrease effect from this concentration to $120 \mu \mathrm{g} / \mathrm{ml}(23.6 \pm 0.8 \mathrm{~min})$. Regarding to the non-polar constituents present in the OAR-PH, the maximum activity is reached at the higher tested concentration $(940 \mu \mathrm{g} / \mathrm{ml})$ and it is evident a dose-dependent effect comprising from this concentration to $240 \mu \mathrm{g} / \mathrm{ml}(15.3 \pm 1.1$ minutes). The observed anesthetic activity was less pronounced for the isolated amide pipercallosidine (AMD1) and for the mixture of seven amides (MIXAMD). The maximum activity is shown at $470 \mu \mathrm{g} / \mathrm{ml}(20.5 \pm 0.9 \mathrm{~min})$ for pipercallosidine and $240 \mu \mathrm{g} / \mathrm{ml}(20.8 \pm 0.5 \mathrm{~min})$ for the mixture of amides. This difference in the anesthetic effect suggests a more efficient action induced by combination of seven amides present in the sample of MIXAMD versus only one in the pipercallosidine (AMD1). It is interesting to note that at $60 \mu \mathrm{g} / \mathrm{ml}$, the equivalent molar concentration of the amide pipercallosidine $(0.19 \mathrm{mM})$ and lidocaine $(0.26$ $\mathrm{mM}$ ) caused a blockage of $9.3 \pm 0.8$ and $15.2 \pm 1.2$ min, respectively.

Species from the genus Ottonia have been described as plants popularly used for the treatment of oral pain due to their analgesic properties. In 1985 the amide piperovatine was first isolated from $O$. vahlii, a traditionally plant species used as analgesic for oral proposes in Trinidad and Tobago. McFerren and Rodriguez (1998) studied the species Piper piscatorum (Piperaceae), which is used in Brazil as a fish stunning plant. Roots of $P$. piscatorum are used in Brazilian traditional medicine as an oral mucosa pain remedy due to 


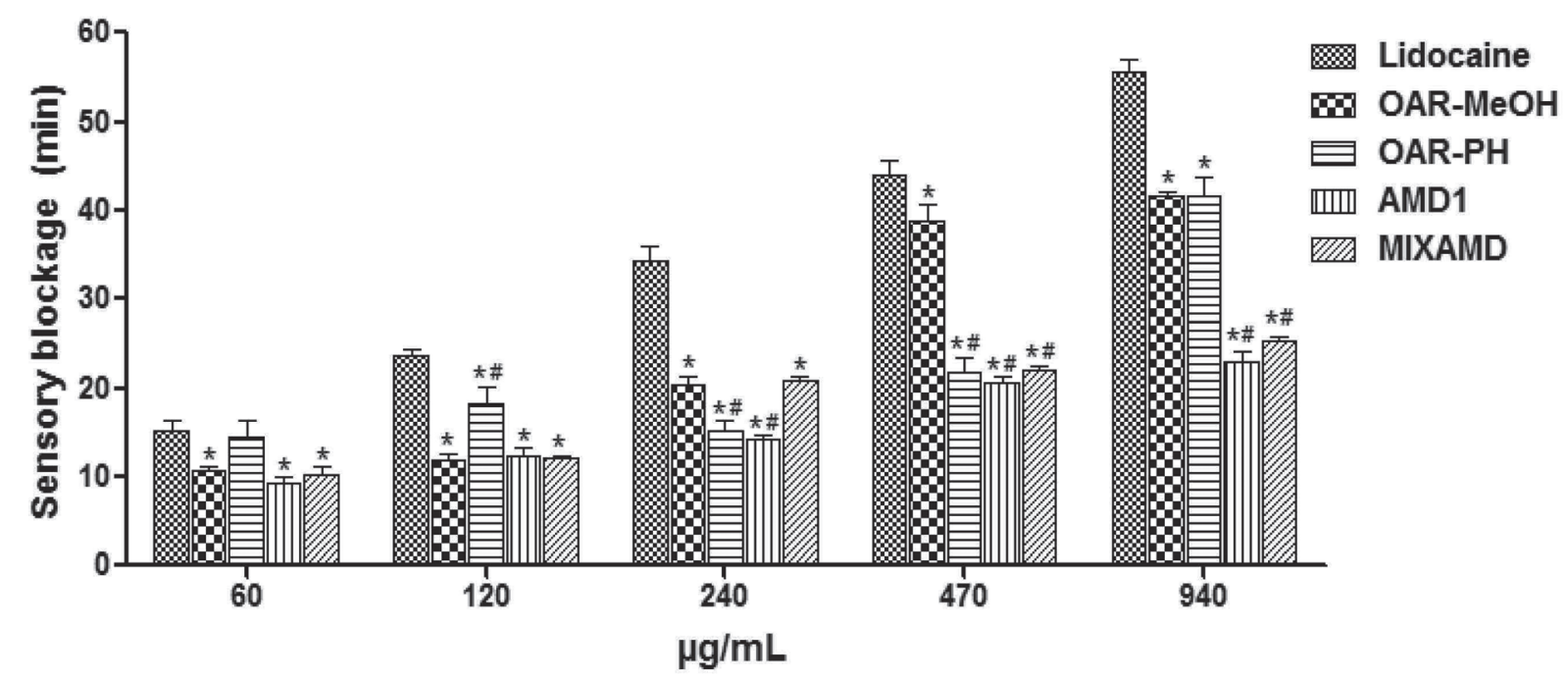

Figure 2 - Duration of anesthesia induced by intradermal administration in guinea pigs of lidocaine $(n=5), O A R-M e O H ~(n=4)$, OAR-PH $(\mathrm{n}=4)$ and amides AMD1 $(\mathrm{n}=4)$ and MIXAMD $(\mathrm{n}=4)$. The bar represents the mean \pm SEM. ${ }^{*} p<0.05$ vs. lidocaine; ${ }^{*} p$ $<0.05$ vs OAR-MeOH.

the presence of piperovatine. Investigations at the University of Illinois at Chicago confirmed the analgesic principle of the roots and stems of Ottonia frutescens (Piperaceae) as the amide piperovatine (Makapljgay et al. 1983).

Possibly, the mechanism of action of the mixtures of amides and pipercallosidine is through voltage-sensitive sodium channels. It was shown that piperovatine is responsible to affect the voltage gated sodium channels of the Periplaneta americana (cockroach) neuronal cell cultures, as well as for the mechanism of sialogoge activity of Piper piscatorum (McFerren et al. 2002). Also, it was demonstrated that isobutylamides act in these channels and the length of the alkenyl chain and the location of unsaturation in the structure influence the activation and sodium uptake. Isobutylamides with seven carbon atoms in the acid chain and an aromatic portion at the end of the chain (same as pipercallosidine) were active only on sodium channels but not in the sodium uptake (Ottea et al. 1990). Since Ottea and co-works assayed only nine different isobutylamides, it is crucial the synthesis of all pure compounds (valeramide and pipercallosidine) as well as the other amides from the mixture (MIXAMD) to: (a) proceed to tests in voltage-sensitive sodium channels and sodium uptake; (b) increase the number of amides and animals in the local anesthetic experiment. Thus, it will be possible to propose a better correlation between chemistry and activity and to perform toxicological evaluations.

The search for new local anesthetics of natural resources with features such as prolonged effect, low latency, high power selective blocking of sensory fibers and local or systemic low toxicity aroused our interest in Piperaceae species and its use in folk medicine as anesthetic. The anesthetic potential demonstrated for the methanolic extract from roots, its $n$-hexane partition and amides from $O$. anisum is in agreement with ethnobotanical survey since confirm the popular knowledge in the traditional use of plants of the genus Ottonia as pain relief, specially related with toothache. Our findings confirm for the first time the local anesthetic properties of $O$. anisum. Besides, this ethnobotanical survey led to the isolation and chemical characterization of eight $\mathrm{N}$-alkylamides 
that contributes to enrich the chemistry of $O$. anisum, a Piperaceae species from the Brazilian Atlantic forest.

\section{MATERIALS AND METHODS}

\section{PHYTOCHEMICAL INVESTIGATION}

\section{General Procedure}

Silica gel (Merck, 60-200 mesh) was employed for column chromatography separation, whilst analytical TLC was performed using silica gel 60 PF254 layers (Merck). Solvents for column chromatography separation as well as for GC-MS and NMR analysis were from Tedia (Brazil).

\section{Plant Material}

The plant material was collected in Xerém, Duque de Caxias, in Rio de Janeiro State (Brazil), in February 2012. The botanical voucher was identified by Dr. Elsie Franklin Guimarães as Ottonia anisum Spreng. and a sample was deposited at the Herbarium (HB) of the Rio de Janeiro Botanical Garden (JBRJ), registered under number RB 393494.

\section{Extract Preparation and Isolation of Pure}

Compounds

Dried and powdered roots (100 g) of O. anisum were extracted by static maceration with methanol $(\mathrm{MeOH})$ at room temperature. The resulting solutions were filtered and the solvent was evaporated under reduced pressure yielding a crude methanolic extract from roots (OAR-MeOH, $8 \mathrm{~g}$ ). A small amount of this extract (10 mg) was tested for local anesthetic activity. Once a local anesthetic activity was detected, the crude methanolic extract was fractioned by liquid-liquid partition with solvent gradient system affording partitions in $n$-hexane, dichloromethane, ethyl acetate and $n$-buthanol. A CG-MS analysis of the $n$-hexane partition (OAR-PH) showed a rich amides content ( $\mathrm{m} / \mathrm{z}$ signals compatible with known amides from Piperaceae species). The $n$-hexane partition of the methanolic extract from roots of O. anisnum (OAR$\mathrm{PH})$ was submitted to column chromatography over silica gel, with gradient of $n$-hexane-ethyl acetate-methanol as mobile phases, at increasing polarities. In total, 60 fractions were obtained. A wide content range of amides was found in the OAR-PH. The fractions 71-73 (50 mg) were analyzed by GC-MS allowing the characterization of a mixture of seven amides: valeramide, 4,5-dihydropiperlonguminine, $\mathrm{N}$-isobutil6-piperonil-2-hexenamide, piperovatine, dihydropipercallosidine, pipercallosidine and pipercallpsine. An amount of $35 \mathrm{mg}$ of the amide mixture was purified by column chromatography over silica gel, using mixtures of $n$-hexane and ethyl acetate as mobile phases. A total of 65 fractions were collected that were re-united in accordance with TLC profile. This chromatography procedure afforded pure valeramide ( $3 \mathrm{mg}$, fractions 29-32), piperine (2 $\mathrm{mg}, 16-19)$ and from fractions 22-26, that were re-crystallization with $\mathrm{MeOH}$, pipercallosidine (12 mg). Piperine was not identified in the amide mixture probably due to coelution. The structures of the pure compounds were established by MS fragmentation pattern (GCMS analysis), and ${ }^{1} \mathrm{H}$ and ${ }^{13} \mathrm{C}$ RMN analysis with data comparison with literature records (Parmar et al. 1997, McFerren and Rodriguez 1998). The structures of the identified compounds are reported in figure 1 .

\section{CHEMICAL ANALYZES}

GC-MS Analysis

Qualitative analyses were carried out on a GCQP2010 PLUS Shimadzu equipped with a ZB$5 \mathrm{MS}$ fused silica capillary column (30 $\mathrm{m} \times 0.25$ $\mathrm{mm}$ i.d. $\mathrm{x} 0.25 \mu \mathrm{m}$, film thickness). The operating temperatures used were: injector $270{ }^{\circ} \mathrm{C}$, detector 
$290{ }^{\circ} \mathrm{C}$ and column oven $60{ }^{\circ} \mathrm{C}$ up to $290{ }^{\circ} \mathrm{C}(10$ ${ }^{\circ} \mathrm{C} / \mathrm{min}$ ). Helium at $1.0 \mathrm{ml} / \mathrm{min}$ was used as carrier gas. The amides were identified by comparison of their mass spectra and fragmentation pattern with published data (Parmar et al. 1997) and computer matching with WILEY 275 and National Institute of Standards and Technology (NIST 3.0) libraries provided with the computer controlling the GC-MS system.

\section{Nuclear Magnetic Resonance Spectroscopy}

The pure compounds obtained from leaves and roots of $O$. anisum were analyzed by ${ }^{1} \mathrm{H},{ }^{13} \mathrm{C}-\mathrm{NMR}$ and recorded on a Varian VNMRS 500 spectrometer. The chemical shifts were determined in DMSO- $\mathrm{d}_{6}$, using TMS as the internal standard. The signals of the NMR analyses were compared to the literature data (Parmar et al. 1997, McFerren and Rodriguez 1998).

\section{BIOLOGICAL INVESTIGATION}

\section{Animals}

Tests were performed in male guinea pigs (Cavia porcellus) (400-500 g), maintained in special cages and housed in a temperature $\left(24^{\circ} \mathrm{C}\right)$ and humidity $(60 \%)$ controlled environment. Water and food were available ad libitum. The experimental protocol used in this study was approved by the Ethics for Animal Welfare and Use Committee of the Centro de Ciências da Saúde (CEUACCS) of Universidade Federal do Rio de Janeiro (Application \#DFBCICB058).

\section{Local Anesthetic Activity}

All assays for testing local anesthetic activity was based on publications of Bülbring Wajda and Henn (1945) (Bülbring and Wadja 1945), in which the guinea pigs were submitted to trichotomy on the dorsal region at day before testing. Seven round areas of approximately of $1.5 \mathrm{~cm}$ in diameter were drawn. Six of these were considered testing area in which $0.1 \mathrm{ml}$ the solutions were injected by intradermal (i.d.) route. Saline was injected $(0.1 \mathrm{ml})$ in the remaining spot. Decreasing concentrations of the extracts and amides from 940 $\mu \mathrm{g} / \mathrm{ml}$ to $60 \mu \mathrm{g} / \mathrm{ml}$ were administered in triplicate. Therefore, each animal received two different concentrations and four different animals $(n=4)$ were used to average one concentration. The results obtained from the isolated plant material were compared to the standard local anesthetic, lidocaine. The test was performed in the following samples isolated as above: OAR-MeOH, OAR-PH, pipercallosidine (AMD1) and amides rich fraction of 4,5-dihydropiperlonguminine, valeramide, pipercallosidine, dihydropipercallosidine, pipercallpsine, piperovatine and $N$-isobutil-6piperonil-2-hexenamide (MIXAMD). Inhibition of the motor reflex in response to pinch of the delimited region of the skin carried out by a sharp forceps was used as a parameter of local anesthetic activity. The parameter evaluated was the duration of anesthesia, defined as time between the beginning and ending of the blockade to painful stimuli. This classic protocol is in accordance with the Pharmacopoeia (Ludena 1969). The data are presented as mean \pm standard error of mean (SEM) $(n=4$ for samples obtained from the plant, and $n=5$ for lidocaine). Effect of each sample was separately compared to lidocaine or OAR-MeOH group using analysis of variance (ANOVA) to verify significance between two means. The statistical level of significance was for $p<0.05$.

\section{ACKNOWLEDGMENTS}

The authors thank to financial support to Coordenação de Aperfeiçoamento de Pessoal de Nível Superior (CAPES) and Conselho Nacional de Desenvolvimento Científico e Tecnológico (CNPq). 


\section{REFERENCES}

AGRA MF, FREITAS PF AND BARBOSA-FILHO JM. 2007. Synopsis of the plants known as medicinal and poisonous in Northeast of Brazil. Braz J Pharmacog 17(1): 114-140.

AHMAD N, FAZAL H, ABBASI HB, FAROOQ S, ALI M AND KHAN MA. 2012. Biological role of Piper nigrum L. (Black pepper): A review. Asian Pac J Trop Biomed 2: S1945-S1953.

AZEVEDO SKS AND SILVA IM. 2006. Plantas medicinais e de uso religioso comercializadas em mercados e feiras livres no Rio de Janeiro, RJ, Brasil. Acta Bot Bras 20(1): 185-194.

BEZERRA DP, PESSOA C, MORAES MO, SAKER-NETO N, SILVEIRA ER AND COSTA-LOTUFO LV. 2013. Overview of the therapeutic potential of piplartine (piperlongumine). Eur J Pharm Sci 48: 453-463.

BOONEN J, BRONSELAER A, NIELANDT J, VERYSER L, TRÉ G AND SPIEGELEER B. 2012. Alkamid database: Chemistry, occurrence and functionality of plant $N$-alkylamides. J Ethnopharmacol 142: 563-590.

BÜLBRING E AND WADJA I. 1945. Biological comparison of anaesthetics. J Pharmacol Exp Ther 85: 78-84.

COLVARD MD AND CORDELL GA. 2008. Rationalizing the Study of Plants for the Treatment of Oral Pain. Curr Chem Biol 2: 140-152.

COLVARD MD, CORDELL GA, VILLALOBOS R, SANCHO G, SOEJARTO DD, PESTLE W, ECHEVERRI TL, PERKOWITZ KM AND MICHEL J. 2006. Survey of medical ethnobotanicals for dental and oral medicine conditions and pathologies. J Ethnopharmacol 107: 134142.

COSTA SS AND MORS W. 1981. Amides of Ottonia corcovadensis. Phytochemistry 20(6): 1305-1307.

CULP WC JR AND CULP WC. 2011. Practical Application of Local Anesthetics. J Vasc Interv Radiol 22(2): 111-118.

CUNICO MM, CARVALHO JLS, AUER CG, GRIGOLETTI JR A, DELLEMONACHE F, KERBER VA, MIGUEL MD AND MIGUEL OG. 2005. Gênero Ottonia: uma revisão das principais características botânicas, fitoquímicas e biológicas. Rev Bras Plantas Med 7(2): 17-21.

DE ARAÚJO DR, PINTO LMA, BRAGA AFA AND DE PAULA E. 2003. Formulações de anestésicos locais de liberação controlada: aplicações terapêuticas. Rev Bras Anestesiol 53(5): 663-671.

DIPPENAAR JM. 2007. Local Anesthetic toxicity. SAJAA 13(3): 23-28.

ERNST AA, MARVEZ E, NICK TG, CHIN E, WOOD E AND GONZABA WT. 1995. Lidocaine adrenaline tetracaine gel versus tetracaine adrenaline cocaine gel for topical anesthesia in linear scalp and facial lacerations in children aged 5 to 17 years. Pediatrics 95(2): 255-258.

GIESBRECHT AM, ALVARENGA MA AND GOTTLIEB OR. 1981. (2E, 4E)-N-isobutyl-9-piperonyl-nona-2,4- dienoic amide from Ottonia anisum. Planta Med 43: 375 377.

GOTTLIEB OR. 1982. Ethnopharmacology versus chemosystematics in the search for biologically active principles in plants. J Ethnopharmacol 6: 227-238.

GREGER H. 2016. Alkamides: a critical reconsideration of a multifunctional class of unsaturated fatty acid amides. Phytochemistry Rev 15(5): 729-770.

JARAMILLO MA AND MANOS PS. 2001. Phylogeny and patterns of floral diversity in the genus Piper (Piperaceae). Am J Bot 88: 706-716.

KARYA N, COSSON C AND MAZOIT JX. 2012. Comparative effect of lidocaine, bupivacaine and RAC 109 on myocardial conduction and contractility in the rabbit. Eur J Pharmacol 691: 110-117.

KIM CH, OH Y, CHUNG JM AND CHUNG K. 2001. The changes in expression of three subtypes of TTX sensitive sodium channels in sensory neurons after spinal nerve ligation. Mol Brain Res 95(1-2): 153-161.

LEITÃO F, LEITÃO SG, FONSECA-KRUEL V S, SILVA IM AND MARTINS K. 2014. Medicinal plants traded in the open-air markets in the State of Rio de Janeiro, Brazil: an overview on their botanical diversity and toxicological potential. Braz J Pharmacog 24: 225-247.

LIPKIND GM AND FOZZARD HA. 2005. Molecular Modeling of Local Anesthetic Drug Binding by VoltageGated Sodium Channels. Mol Pharmacol 68(6): 16111622.

LUDUENA FP. 1969. Duration of Local Anesthesia. ANNU Rev Pharmacol 9: 503-520.

MCFERREN MA, CORDOVA D, RODRIGUEZ E AND RAUH J. 2002. In vitro neuropharmacological evaluation of piperovatine, an isobutylamide from Piper piscatorum (Piperaceae). J Ethnopharmacol 83: 201-207.

MCFERREN MA AND RODRIGUEZ E. 1998. Piscicidal properties of Piper piscatorum (Piperaceae). J Ethnopharmacol 60: 183-187.

MAKAPLJGAY HC, SOEJARTO DD, KINGHORN AD AND BORDAS E. 1983. Piperovatine, the Tongue-Numbing Principle of Ottonia frutescens. J Ethnopharmacol 7: 235238.

MARQUES AM, VELOZO LSM, GUIMARÃES EF AND KAPLAN MAC. 2008. Caracterização de derivado arilbutanoídico em folhas e raízes de Ottonia anisum Sprengel. Braz J Pharmacog 18: 709-712.

MARQUESAM, VELOZOLS, MOREIRADL, GUIMARÃES EF AND KAPLAN MAC. 2011. Aristolactams from roots of Ottonia anisum (Piperaceae). Nat Prod Commun 6(7): 939-942.

MOREIRA DL, GUIMARÃES EF AND KAPLAN MAC. 1997. Butyl-3,4-methylenedioxybenzene as the major constituent of the essential oil from Ottonia anisum. J Essent Oil Res 9: 565-568. 
NAU CE AND WANG GK. 2004. Interactions of local anesthetics with voltage-gated $\mathrm{Na}^{+}$Channels. J Membr Biol 201(1): 1-8.

OLIVEIRA GL ET AL. 2013. Chemical study and larvicidal activity against Aedes aegypti of essential oil of Piper aduncum L. (Piperaceae). An Acad Bras Cienc 85: 12271234.

OTTEA JA, PAYNE GT AND SODERLUND DM. 1990. Action of Insecticidal $N$-Alkylamidesat Site 2 of the Voltage-Sensitive Sodium Channel. J Agri Food Chem 38: 1724-1728.

PARENTE CET AND ROSA MMT. 2001. Plantas comercializadas como medicinais no Município de Barra do Piraí, RJ. Rodriguésia 52: 47-59.

PARMAR VS, JAIN SC, BISHT KS, JAIN R, TANEJA P, JHA A, BOLL PM ET AL. 1997. Phytochemistry of the genus Piper. Phytochemistry 46(4): 591-673.
PARMAR VS, JAIN SC, GUPTAS, TALWAR S, RAJWANSHI VK, KUMAR R, WENGEL J ET AL. 1998. Polyphenols and alkaloids from Piper species. Phytochemistry 49(4): 1069-1078.

PICARD G, VALADEAU C, ALBÁN-CASTILLO J, ROJAS R, STARR JR, CALLEJAS-POSADA R, BENNETT SAL AND ARNASON JT. 2014. Assessment of in vitro pharmacological effect of Neotropical Piperaceae in GABAergic bioassays in relation to plants traditionally used for folk illness by the Yanesha (Peru). J Ethnopharmacol 155: 1500-1507.

QIU S, SUN H, ZHANG AX, HONG-YING Y, HAN Y AND WANG XJ. 2014. Natural alkaloids: basic aspects, biological roles, and future perspectives. Chin J Nat Med 12(6): 0401-0406.

RUETSCH YA, BÖNI T AND BORGEAT A. 2001. From cocaine to ropivacaine: the history of local anesthetic drugs. Curr Top Med Chem 1(3): 175-182. 